\title{
Distanční výuka - krok vpřed nebo krok vzad?
}

\section{Distance learning - a step forward or a step backwards?}

\author{
Zuzana Hořká
}

\begin{abstract}
Abstrakt: Přechod na distanční výuku znovu otevřel otázku metodiky výuky cizích jazyků. Zimní semestr 2020/21 proběhl celý on-line, což se stalo výzvou zejména pro studenty prvních ročníků, kteří museli zvládnout přechod na zcela jinou formu studia, aniž by se mohli osobně seznámit s vysokoškolským prostředím. Vedení Matematicko-fyzikální fakulty se vzhledem k situaci na jaře 2020 rozhodlo přijmout všechny zájemce o studium bez přijímacích zkoušek, což do prvního ročníku přivedlo české i zahraniční studenty se značnými rozdíly ve znalosti angličtiny. Situace byla nová i pro vyučující, kteří přišli o možnost na tradičním úvodním soustředění předat studentům informace a doporučit jim úroveň kurzu angličtiny podle jejich znalostí.

Článek shrnuje zkušenosti z prvního semestru vyučovaného pouze distanční formou. Rozborem anonymního dotazníku studentů kurzů prvního ročníku Anglický jazyk pro mírně pokročilé (přibližně A2/B1 podle CEFR) a Anglický jazyk pro středně pokročilé (přibližně B2/C1 podle CEFR) se snaží vyhodnotit používané aktivity a navrhnout zlepšení pro případnou on-line výuku v dalších semestrech.
\end{abstract}

Klíčová slova: distanční výuka, anglický jazyk, e-learning, 1. ročník VŠ, dotazník

\section{Abstract:}

The transition to distance learning has reopened the question of foreign language teaching methodology. Winter semester 2020/21 took place entirely on-line, which became a challenge especially for first-year students, who had to adapt to a completely different form of study without being able to get acquainted with the university environment in person.

Due to the situation in spring 2020, the management of the Faculty of Mathematics and Physics decided to accept all those interested in studying without the entrance exam, which brought to the first year both Czech and foreign students with significant differences in their knowledge of English. The situation was also new for teachers, who lost the opportunity to pass on information to students at the traditional introductory orientation.

The article summarizes the experience from the first semester taught only in the form of distance learning. By analyzing an anonymous questionnaire of first-year students of two courses English for Intermediate Students (approximately A2 / B1 according to CEFR) and English for Intermediate Students (approximately B2 / C1 according to CEFR) it tries to evaluate the activities used and suggest improvements for possible on-line teaching in future semesters.

Key words: distance learning, English, e-learning, freshmen, survey 
Způsob výuky angličtiny jako cizího jazyka je v odborných i laických kruzích často diskutovaným tématem a vyvíjí se spolu se sociálním i technologickým vývojem společnosti. Přechod na distanční formu výuky přivedl tuto otázku znovu do popředí zájmu studentů i učitelů.

S vyučováním angličtiny mám celoživotní zkušenosti jako studentka základní i střední školy s rozšířenou výukou angličtiny, posluchačka Filozofické fakulty Univerzity Karlovy, ale hlavně jako vyučující angličtiny jako cizího jazyka na Katedře jazykové př́pravy Matematicko-fyzikální fakulty Univerzity Karlovy, kde působím od roku 1993.

Přesto mě náhlý přechod na distanční formu výuky, který si na jaře 2020 vyžádala epidemická situace, zastihl, dá se ř́ci, úplně nepřipravenou. Když se v záŕí ukázalo, že distanční výuka nezůstane pouze na úrovni krátkodobé improvizace a bylo nanejvýš pravděpodobné, že celý semestr proběhne distančně, bylo mi jasné, že přizpůsobit vedení kurzu těmto podmínkám pro mne bude úplně novou výzvou.

Tou největší výzvou byla výuka studentů prvního ročníku. Vzhledem k situaci byli přijati všichni, kteř́ projevili o studium na fakultě zájem. Studenti, kteří „přicházeli“ z různých míst České republiky, z Běloruska, Lotyšska, Ruska, Slovenska, Ukrajiny a dalších zemí. Studenti s různým zázemím, kteří se stali posluchači Matematicko-fyzikální fakulty, ale školu, spolužáky, učitele a mnohdy ani Prahu nikdy neviděli.

Naštěstí je prostředí Matematicko-fyzikální fakulty prostředím velmi motivujícím. Studenti jsou připraveni tvrdě pracovat a vedení fakulty ponechává $\mathrm{v}$ rámci doporučených nástrojů vyučujícím volnost ve volbě, jakým způsobem budou studenty oslovovat. Jak tedy zaujmout studenty, kteři se obvykle pohybují v $n$ dimenzích prostřednictvím maximálně dvou, na které nás on-line výuka omezila?

V zimním semestru akademického roku 2020/2021 jsem vedla dva předměty pro studenty prvního ročníku: tři paralelky předmětu Anglický jazyk pro středně pokročilé a jednu paralelku předmětu Anglický jazyk pro mírně pokročilé.

Pro výuku jsem po určitém váhání zvolila kombinaci on-line setkávání prostřednictvím Zoomu a využití nástroje Moodle UK. Na Zoomu jsem se snažila aktivně zapojit do výuky všechny přihlášené studenty, společně jsme opravovali chyby, které $\mathrm{v}$ úkolech zadaných $\mathrm{v}$ Moodlu udělali, a prezentovala jsem jim novou gramatiku a slovní zásobu, nejčastěji pomocí sdílení prezentace $\mathrm{v}$ Power Pointu. $\mathrm{V}$ Moodlu měli studenti možnost se k prezentaci nové látky znovu vrátit a prostřednictvím nástrojů „úkol“ a "test" si probírané jevy procvičit. Požadavkem na úspěšné absolvování celého kurzu bylo splnění všech úkolů a testů, celkem asi 30 zadání v průběhu semestru. 
Z pohledu učitele jsem byla s tímto nastavením celkem spokojená a v druhé polovině semestru jsem netrpělivě očekávala odpovědi na dotazník, o jehož vyplnění jsem studenty anonymně požádala. Měla jsem pocit, že mi starost a úsilí o technické zvládnutí výuky ztížily se studenty kontakt a obávala jsem se, že jsem na rozdíl od prezenční výuky nedokázala přesně rozeznat jejich reakce a že jsem jim touto vzdálenou formou nepředala informace $\mathrm{v}$ dostatečné míře.

Prvním potěšujícím zjištěním byl počet odpovědí, který jsem na zadaný dotazník získala. U předmětu Anglický jazyk pro mírně pokročilé odpovědělo $9 \mathrm{z}$ celkového počtu 15 studentů a u předmětu Anglický jazyk pro středně pokročilé odpovědělo 40 ze zapsaných 50 studentů. Tento vysoký počet studentských reakcí myslím dokazuje, že se studenti cítili rovnoprávnými spolutvůrci výuky.

Novou výzvu představovalo nastavení vhodného tempa synchronní výuky přes Zoom. Zdálo se mi, že přepínání mikrofonů a občasná nesoustředěnost některých studentů tempo komunikace oproti prezenční výuce značně zpomalí, a měla jsem obavy, aby tempo nebylo pomalé až př́liš a studenti se nenudili. Naštěstí jsou posluchači MFF technicky velmi zdatní, svá zařízení dokonale ovládají a vážnější problémy $s$ připojením vždy hravě vyřešili. $Z$ grafů je vidět, že převážná většina studentů obou kurzů byla s tempem výuky spokojena.

Komunikace přes Zoom byla

9 odpovědí

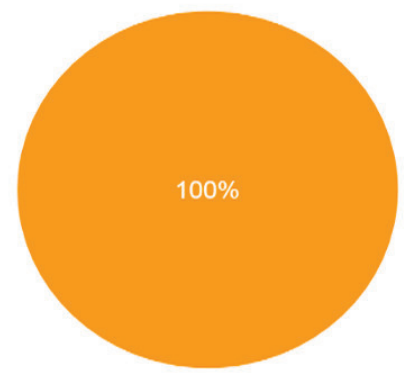

Komunikace přes Zoom byla

40 odpovědi

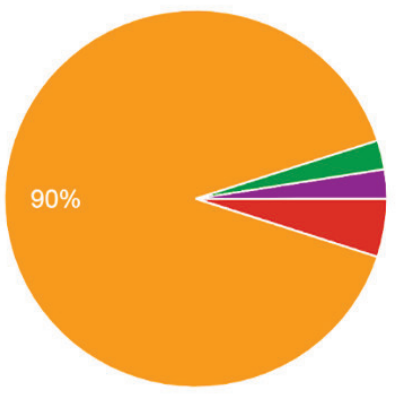

kurz Anglický jazyk pro mírně pokročilé

príliš rychlá

príliš pomalá

tempo mi vyhovovalo

kurz Anglický jazyk pro středně pokročilé

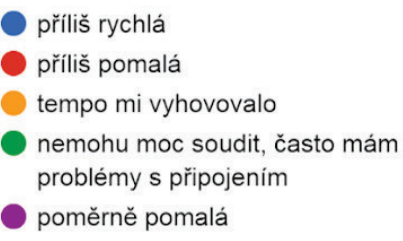


Dalším lehce kontroverzním tématem bylo připojení kamer. Studentům jsem jejich používání sice doporučila, ale nepožadovala jej povinně; jako vyučující jsem měla kameru připojenou vždy po celou dobu našich setkání. Musím podotknout, že vidět při výuce svůj vlastní obličej bylo dalším zajímavým prvkem distanční výuky.

V některých paralelkách měli studenti zapnutou kameru všichni, v některých sotva polovina. Př́čin byla celá řada, často měli studenti potíže s připojením, často však přiznávali různé, někdy až komické důvody jako přítomnost pobíhajících rodinných př́islušníků, přítomnost přítelkyň v pokoji, stav svých pyžam a podobně. Oceňovali však, že vyučující kameru používá a že mají možnost vidět své spolužáky.

Použiti kamer

kurz Anglický jazyk pro mirné pokročlé

9 odpovědi

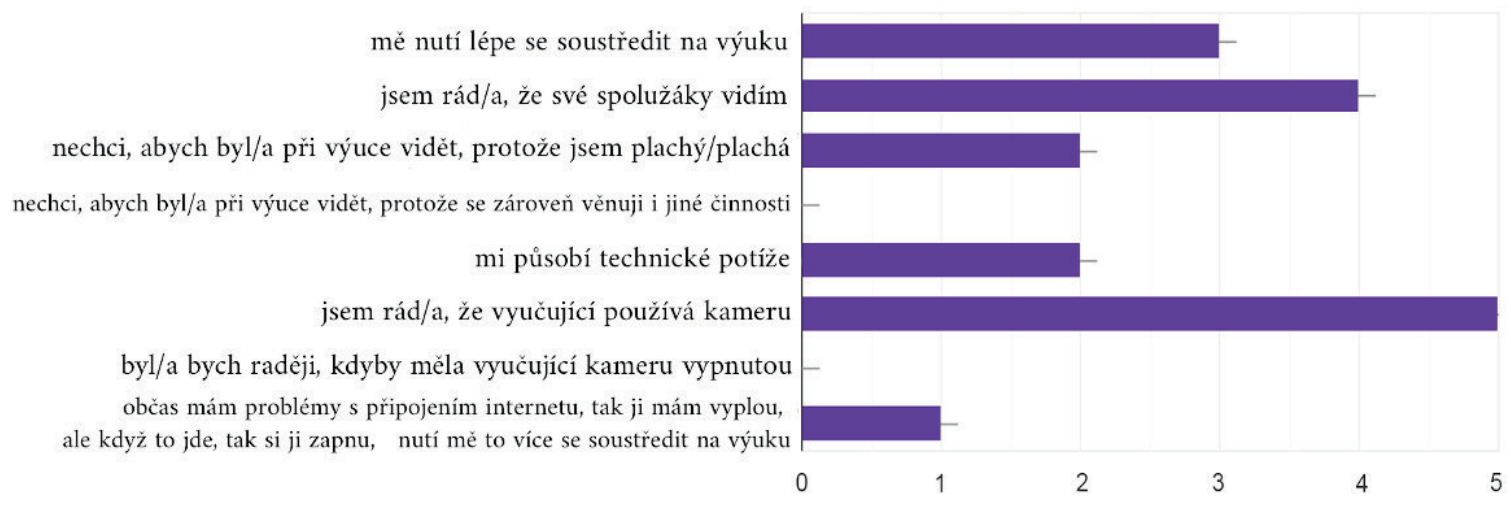

Použiti kamer

kurz Anglický jazyk pro středné pokročilé

39 odpovědí

mě nutí lépe se soustředit na výuku

jsem rád/a, že své spolužáky vidím

nechci, abych byl/a při výuce vidět, protože jsem plachý/plachá

nechci, abych byl/a při výuce vidět, protože se zároveň věnuji i jiné činnosti mi působí technické potíže

jsem rád/a, že vyučující používá kameru

byl/a bych raději, kdyby měla vyučující kameru vypnutou jsem plachá, ale při této hodině mi zapnutá kamera vyhovuje hodina je více

osobně nemám s kamerami při výuce problém (víc se soustředím na online hodinu, nemám tendenci odbíhat)

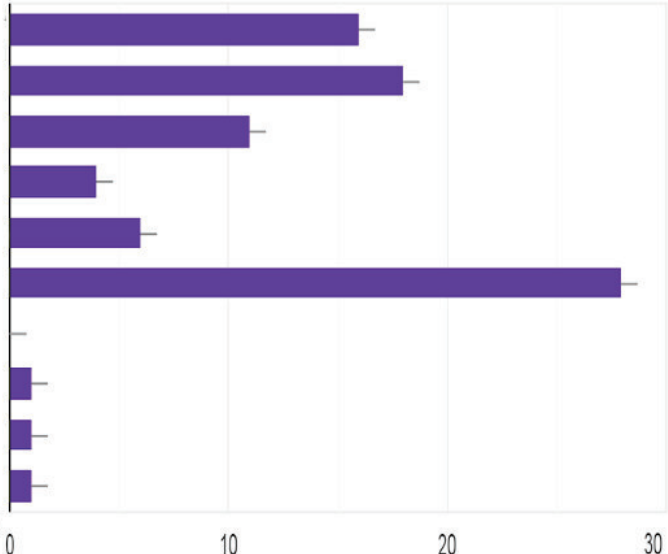

Připojení videa podle mého názoru př́íznivě ovlivňuje on-line výuku, soustředěnost studentů i jejich vzájemný kontakt. $V$ př́štím semestru se budu snažit požadavky nastavit tak, aby měli všichni studenti kameru zapnutou. Komunikace s někým, o kom vůbec nevím, jak vypadá, byla pro mne nová a nezvyklá. $\mathrm{Z}$ odpovědí 
studentů je však vidět, že jim v připojení kamer často brání technické důvody. $\mathrm{V}$ takovém př́ípadě je samozřejmě lepší se výuky zúčastnit alespoň nějakým dostupným způsobem.

Práce ve dvojicích a ve skupinách je ve výuce angličtiny často zařazovanou aktivitou. Profitují z ní zejména pokročilejší studenti a ve větších skupinách je oblíbenou činností na procvičení konverzace. $\mathrm{V}$ on-line výuce je možné tyto aktivity využít v rámci takzvaných „breakout rooms“. Přiznám se, že tuto metodu využívám i při prezenční výuce pouze okrajově a s ohledem na časové možnosti a případné technické problémy jsem ji do on-line výuky nezařadila. Většina studentů měla však s „breakout rooms" zkušenosti z jiných předmětů a chtěla jsem zjistit, zda jim práce v malých skupinách nechybí.

Přál/a bych si využivat breakout rooms

kurz Anglický jazyk pro mírné pokročilé

9 odpovědí
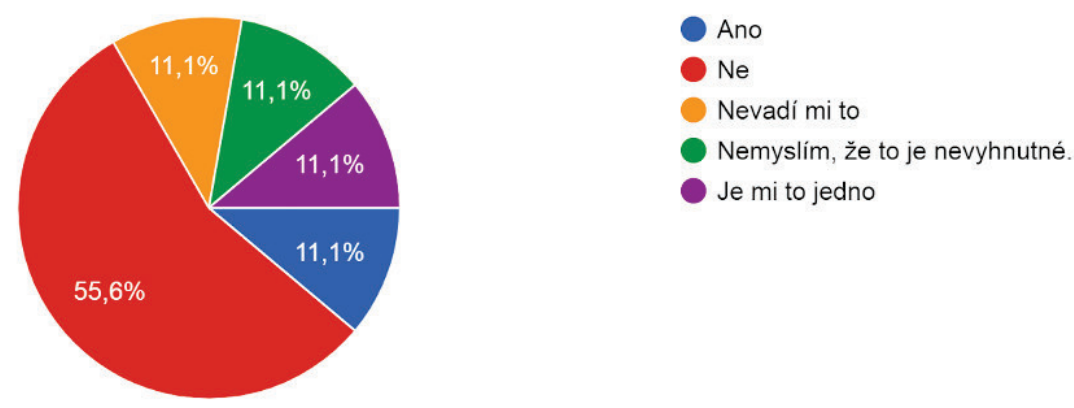

Přál/a bych si využivat breakout rooms

kurz Anglický jazyk pro středně pokročilé

39 odpovědi
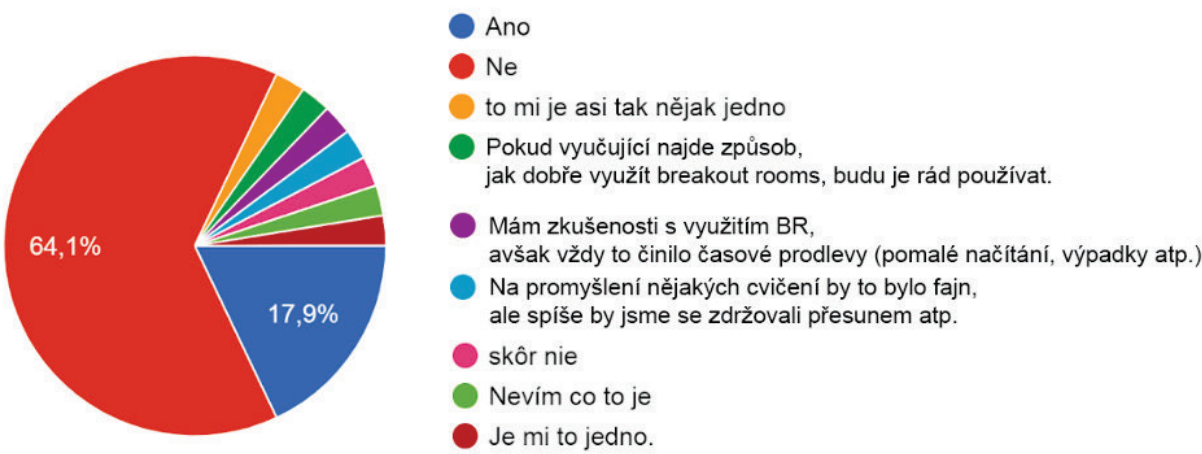

Z odpovědí studentů je vidět, že většina $\mathrm{z}$ nich práci ve skupinách nepostrádala, v letním semestru se ji ale budu snažit v pokročilejších skupinách zařadit.

Další otázka se týkala materiálů, které jsem používala jak při synchronní výuce přes Zoom, tak v prostředí Moodlu. 


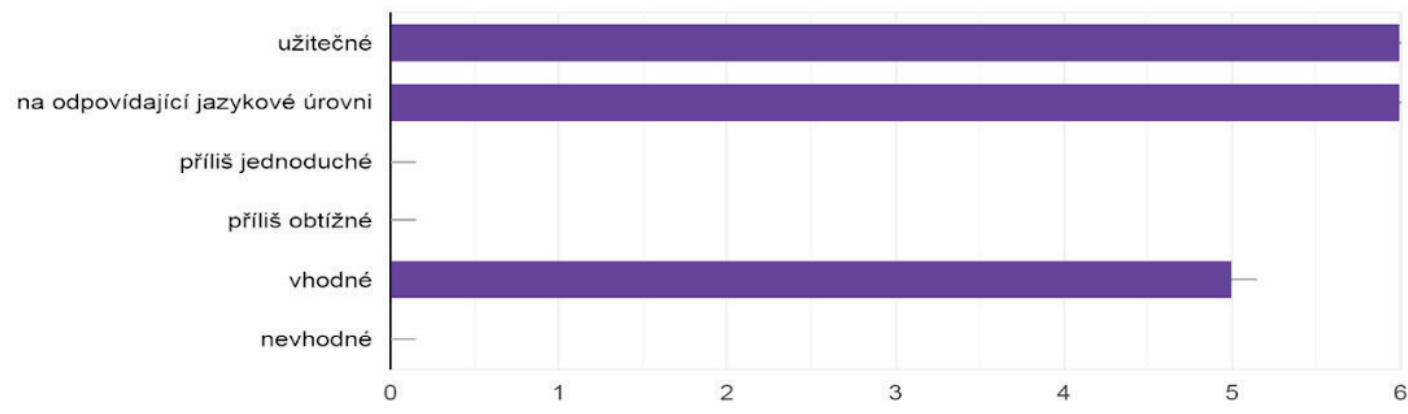

Materiály ve výuce mi připadaly

39 odpovědí

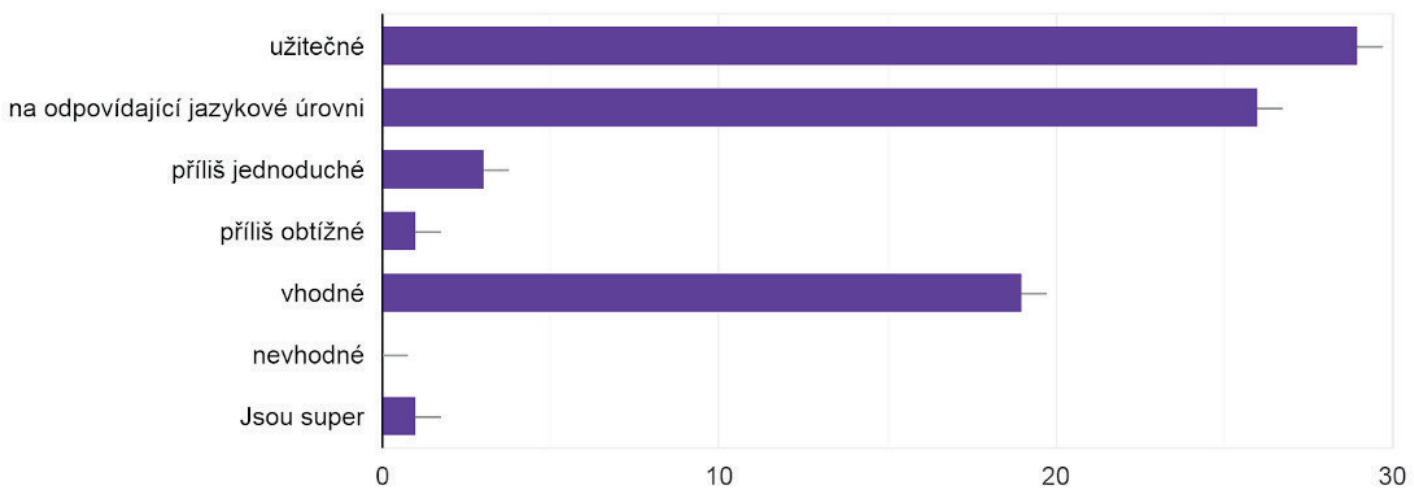

Studenti kurzu pro mírně pokročilé se shodli na užitečnosti, vhodnosti a odpovídající úrovni využitých materiálů. U pokročilejších studentů se díky většímu počtu respondentů objevily reakce jak na př́lišnou jednoduchost, tak na př́lišnou obtížnost materiálů. $\mathrm{V}$ kurzu této úrovně pokročilosti není ani při prezenční výuce jednoduché nastavit ideální obtížnost. V rámci každé skupiny, ve které je obvykle 15 až 17 studentů, je poměrně velký rozdíl mezi těmi nejpokročilejšími a nejméně pokročilými. Poměr uvedených odpovědí ale ukazuje, že i v tomto distančním kurzu pro středně pokročilé byla pro většinu účastníkủ úroveň obtížnosti nastavena správně. Studenty přidaná odpověd” „jsou super“ mi dodala motivaci k př́ípravě obdobných materiálů i do budoucna.

Moodle pro mne představoval úplně novou výzvu. Dosud jsem ho pro podporu prezenčních kurzů nevyužívala, ale čím více jsem se s nástrojem seznamovala, tím více jsem oceňovala jeho možnosti. Nenahraditelná je přehlednost zadávání úkolů i jejich archivace. Pracovala jsem zejména s režimy „úkol“ a "test“, kde vyučující předem zadává správné odpovědi. Drobnou nevýhodou je, že se program chová jako robot a všechny odchylky od nastavené odpovědi vyhodnocuje jako nesprávné. 
Stačí například použití české klávesnice při zadání apostrofu, přidat tečku za větou a podobně, což bylo pro některé studenty poněkud matoucí. Díky svému zaměření to však velmi rychle pochopili a k těmto odchylkám docházelo jen zřídka. Obrovskou výhodou automatického opravování je, že program sám odpovědi vyhodnotil, a tím mi při velkém počtu studentů značně ušetřil čas. Všechny vytvořené úlohy navíc budu moci použít v dalších kurzech a dokonce je i jednoduše sdílet se svými kolegy.

V Moodlu měli studenti možnost vrátit se k prezentacím a materiálům použitým při synchronní výuce. Prostřednictvím Moodlu jsem také pracovala s poslechovými úkoly. Z grafư je vidět, že většina studentů považovala zadání za užitečná a zábavná, pouze malé procento z nich je považovalo za nudná nebo je nechtělo vůbec.

Informace, úkoly a testy $v$ Moodlu pro mne byly

kurz Anglický jazyk pro mírně pokročilé 9 odpovědí

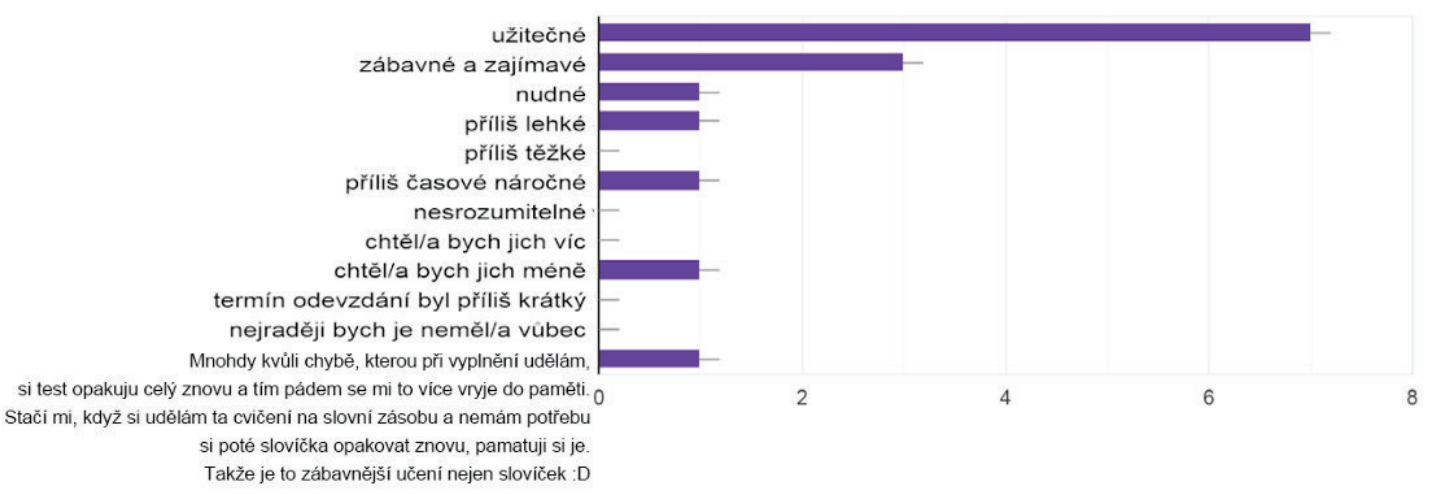

Informace, úkoly a testy $v$ Moodlu pro mne byly

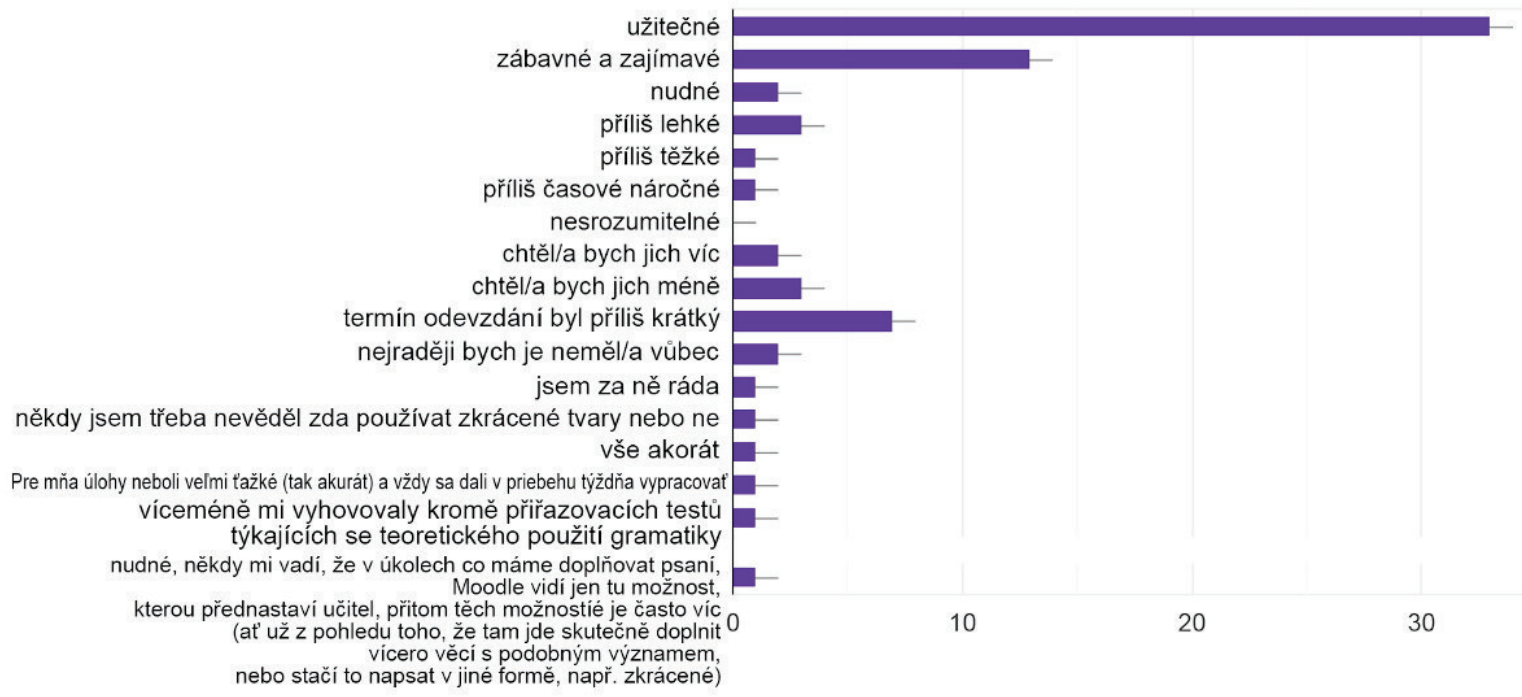


V další otázce posuzovali studenti, v čem se zlepšili. Potěšilo mě hodnocení méně pokročilých studentů, kteří se shodli na tom, že se alespoň trochu zlepšili ve všech jazykových dovednostech; u pokročilejších studentů mě nepřekvapilo, že nejlepší zlepšení zaznamenali v gramatice a slovní zásobě a hodnocení „vủbec ne“ se objevilo zejména u čtení a psaní. $V$ příštím semestru se u pokročilejších kurzů a $\mathrm{v}$ závislosti na velikosti skupin budu snažit zařazovat krátké eseje, aby se měli studenti možnost zlepšovat i $\mathrm{v}$ této jazykové dovednosti.

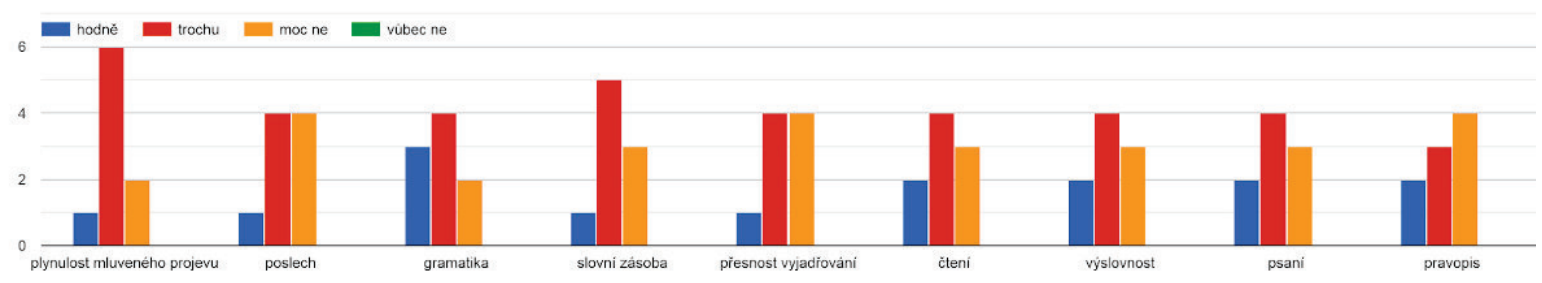

V následujicich kategoriich jsem se zlepšil/a

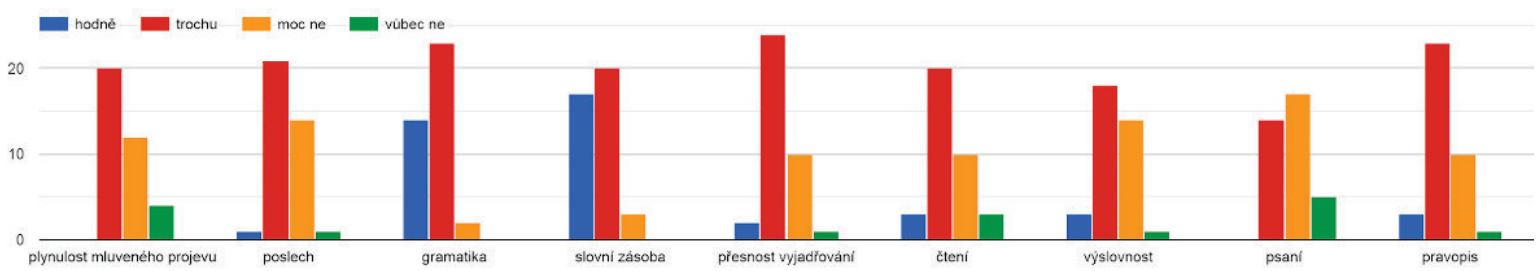

V několika otevřených otázkách se studenti vyjadřovali $\mathrm{k}$ tomu, co se jim na cvičení líbilo či nelíbilo a co jim chybělo. Kladně hodnotili moji snahu všechny zapojit do výuky, pravidelnost výuky a vracení se $\mathrm{k}$ úkolům, které vypracovávali přes Moodle. Ocenila jsem i komentáře typu „Utíká to celkem rychle:)“, které, jak doufám, sdělovaly, že se studenti při výuce př́liš nenudí. Některým studentům chybělo psaní delších esejí, které do výuky v následujícím semestru určitě zařadím.

V otázkách týkajících se vystupování vyučující mne velice potěšily komentáře jako „bylo mi na hodinách dobře“, „hodiny mě bavily“; radost jsem měla i z četných komentářů, které zmiňovaly vedení výuky se smyslem pro humor, protože jsem měla strach, že právě humor se $\mathrm{v}$ on-line výuce může velmi snadno ztratit. 
V rámci dotazníku hodnotili studenti také cvičení jako celek. Předem nastavené možnosti byly čtyři: dobré, spíše dobré, spíše špatné a špatné. Tak jako u všech otázek i tady měli studenti možnost přidat své vlastní odpovědi.

Cvičeni mi celkově připadá

9 odpovědí

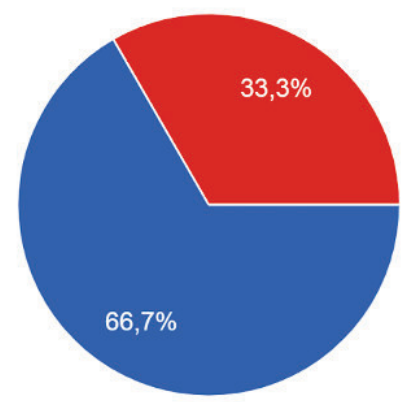

Cvičeni mi celkově připadá

40 odpovědí

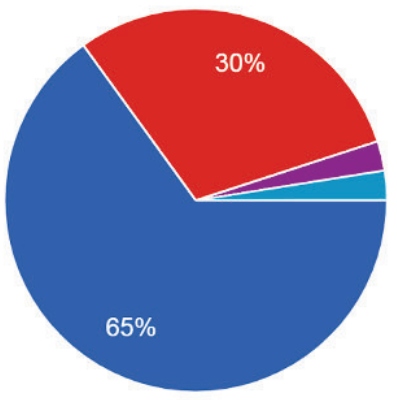

kurz Anglický jazyk pro mírně pokročilé

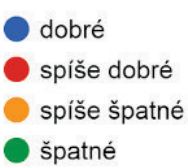

kurz Anglický jazyk pro středně pokročilé

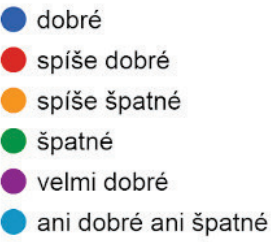

Z odpovědí vyplývá, že byli studenti s cvičením spokojeni, žádná odpověd’ neoznačila cvičení jako špatné ani spíše špatné. Mne potěšila zejména studenty přidaná odpověd” „velmi dobré“.

Z volných odpovědí hodnotících cvičení jako celek bych ráda na závěr vybrala jednu, která mi potvrdila, že i při distanční formě výuky se studenti mohou v angličtině zlepšovat, zároveň však poukazuje i na skutečnost, že prezenční vzdělávání pro ně zůstává stále tou atraktivnější a účinnější formou: „Mám pocit, že jsem se toho hodně naučil, ale zároveň jsem látkou nebyl přehlcen, což velmi oceňuji hlavně v této době, kdy je vzdělávání dost obtížne."

Je tedy distanční výuka krokem vpřed nebo krokem vzad? Pro mne představovala rozhodně velký a vzrušující výlet daleko za hranice komfortní zóny. 


\section{Autorka}

Mgr. Zuzana Hořká, e-mail: zhorka@mbox.troja.mff.cuni.cz, vystudovala obor učitelství angličtiny a češtiny na Filozofické fakultě Univerzity Karlovy. Je členkou Katedry jazykové přípravy Matematicko-fyzikální fakulty Univerzity Karlovy, kde zastává funkci zástupkyně vedoucí. Je garantem výuky angličtiny pro studenty doktorského studia a věnuje se výuce obecného i odborného jazyka studentů prvního a druhého ročníku. 